\title{
Amylolytic Activities Excreted by the Halophilic Archaeon Haloferax mediterranei to Assimilate Available Starch Depend on the Nitrogen Source
}

\author{
Francisco Pérez-Pomares ${ }^{1^{*}}$, Carmen Pire ${ }^{1}$, Anna Vegara ${ }^{1}$, Vanesa Bautista ${ }^{1}$ \\ and María José Bonete ${ }^{1}$ \\ ${ }^{1}$ University of Alicante, Dpto. Agroquímica y Bioquímica, Facultad de Ciencias, Grupo de \\ Biotecnología de Extremófilos, Universidad de Alicante, Carretera San Vicente del Raspeig s $\mathrm{n}$, \\ 03690 San Vicente del Raspeig, Alicante, Spain.
}

\begin{abstract}
Authors' contributions
This work was carried out in collaboration between all authors. Authors FPP, CP and MJB designed the study. Author FPP performed the statistical analysis, wrote the protocol and first draft of the manuscript in collaboration with authors AV and VB. Author VB managed the analyses of the study. Author AV managed the literature searches. All authors read and approved the final manuscript.
\end{abstract}

Article Information

DOI: $10.9734 / \mathrm{JABB} / 2018 / 43040$

Editor(s):

(1) Dr. Mohamed AliAbdel-Rahman, Associate Professor, Department of Botany and Microbiology, Al-Azhar University, Cairo,

(1) Maria Balcerek, Lodz University of Technology, Poland.

(2) Mustafa Ateş, Ege University, Turkey.

(3) Xochitl Ruelas-Chacon, Universidad Autonoma Agraria Antonio Narro, Mexico. Complete Peer review History: http://www.sciencedomain.org/review-history/26355

Original Research Article

Received 09 June 2018

Accepted 17 August 2018

Published 22 September 2018

\begin{abstract}
Several amylolytic activities have been isolated from a controlled growing media containing starch and nitrate or ammonium acetate as a carbon and energy source, excreted by the halophilic archaeon Haloferax mediterranei. These enzymes produced in nitrate-containing medium were different from those produced by the organism when cultured in ammonium acetate-containing medium. Haloferax mediterranei was able to grow optimally in both the media but not in a medium with ammonium chloride and starch as exclusive source of nitrogen and carbon, respectively. Growth was significantly lower when nitrate was replaced by ammonium, although there was significant amylolytic activity in the medium. At least six different activities were obtained in the nitrate-containing medium, but only five for the ammonium containing one. These enzymes displayed a different affinity for starch as a chromatographic matrix, when eluted with maltose in a
\end{abstract}


range from $0.02 \mathrm{M}$ to $0.2 \mathrm{M}$, and differed in their kinetic parameters for starch as a substrate. The average medium length of the products obtained from cracking starch was different for each amylolytic activity, ranging from glucose to larger polysaccharides. Moreover, they exhibited different molecular masses, from 15 to $80 \mathrm{kDa}$. On the other hand, all of them behaved as typical halophilic enzymes, requiring high salt concentrations from $2 \mathrm{M}$ to $4 \mathrm{M} \mathrm{NaCl}$ for stability and activity. Also, it exhibited an optimal $\mathrm{pH}$ ranged from 7 to 8 and showed certain thermophilic behaviour, with maximal activity within $50^{\circ} \mathrm{C}$ to $60^{\circ} \mathrm{C}$. The study of the presence and behaviour of this set of starch degrading enzymes will allow for a better understanding of how halophilic organism obtain the adequate carbohydrates to be incorporated and optimally used.

Keywords: Halophilic archaea; Haloferax mediterranei; Amylolytic enzymes; Isolation and biochemical characterisation; carbon and nitrogen sources.

\section{INTRODUCTION}

Starch represents a readily form to obtain the carbohydrates necessary to compete and succeed in the hard, extreme, media they have to endure. Organisms having the necessary machinery, both intracellular and extracellular enzymes, to hydrolyze them efficiently, are able to access the available glucose and a wide variety of oligosaccharides obtained from carbohydrate macromolecules [1\}, [2].

Due to the complex structure of starch, its digestion occurs in several stages in a great variety of organisms including ourselves, humans [3]. Initially, amylases provide a partial digestion, which breaks down polymeric starch into shorter oligomers, and this partially digested starch is then extensively hydrolysed into smaller oligosaccharides by other glycosylases. The enzymes responsible for these transformations belong, mostly to the a-amylase family. According to their role, we may classify them as endoamylases, exoamylases, debranching enzymes and transferases [4]. Endoamylase cleaves $\alpha-1,4-$ glycosidic bonds in the inner part of a chain, such as $\alpha$-amylase (EC 3.2.1.1), that yields oligosaccharides with an $\alpha$-configuration and $\alpha$-limit dextrins. Exoamylases cleave $\alpha-1,4$ glycosidic bonds in the external part of starch, such as $\beta$-amylase (EC3.2.1.2), yielding maltose and $\beta$-limit dextrin; or both $\alpha-1,4$ and $\alpha-1,6$ glycosidic bonds, as glucoamylase (EC 3.2.1.3) and $\alpha$-glucosidase (EC 3.2.1.20) producing only glucose. Debranching enzymes such as an isoamylase (EC 3.2.1.68) and pullulanase type I (EC 3.2.1.41), only hydrolyse $\alpha-1,6$ glycosidic to yield maltotriose and linear oligosaccharides. Finally, transferases cleave an $\alpha-1,4$ glycosidic bond of a donor molecule and transfer this cut part to another glycosidic acceptor. Amylomaltase (EC 2.4.1.25) and Cyclodextrin glycosyltransferase (EC 2.4.1.19) are transferases that create a new $\alpha-1,4$ glycosidic bond while branching enzyme (EC 2.4.1.18) forms a new $\alpha-1,6$ glycosidic bond. Cyclodextrin glycosyltransferase produces a series of nonreducing cyclic dextrins, namely, $\alpha-, \beta-$ and $\gamma-$ cyclodextrins [2].

Previous reports show that halophilic archaeon can produce two extracellular starch degrading enzymes when it was grown in ammonium acetate medium: a-amylase [5] and cyclodextrin glycosyltransferase [6]. This glycosyltransferase may act degrading and transforming starch in several ways, including both coupling and disproportionation activities, but cyclisation was, by far, its main activity, yielding a mixture of cyclodextrins. Its sequence revealed an open reading frame of $2142 \mathrm{bp}$, corresponding to a protein of 713 amino acids, with high homology with members belonging to the a-amylase family, and was secreted to the extracellular medium by the Tat pathway [6]. On the other hand, the $\alpha-$ amylase already produced a mixture of different dextrins and maltose. Its behaviour is very similar to the amylases from Halobacterium salinarum[7], and Natronococcus amylolyticus[8] and to that from the moderately halophilic bacteria Halomonas meridiana[9]. Besides, grown in a starch-containing medium, it also produces three cytoplasmic activities (AMY1, AMY2, and AMY3), all of them typically halophilic, and reported to produce mainly small oligosaccharides from starch or dextrins. All these enzymes appeared when the organism grew in a media containing ammonium acetate and starch, except AMY2, detected when the organism was in a medium with glycerol as a carbon source [10]. The degradation of starch in an adequate way, previous to its assimilation appears to be essential for its optimal use. The aim of this study of the implied enzymes was a deeper understanding of how the organism succeeds in getting a profit of the starch, in 
different conditions of growth, with different nitrogen sources.

\section{MATERIALS AND METHODS}

\subsection{Growth Conditions and Crude Enzyme Preparation}

H. mediterranei strain R4 (ATCC 33500) [11] was grown in $25 \%(\mathrm{w} / \mathrm{v})$ salts, at $37^{\circ} \mathrm{C}$ temperature and $\mathrm{a} \mathrm{pH}$ of 7.2 and supplemented with different carbon and nitrogen sources. Three different media were used, named as $A, B$ and $C$. Medium A contained $0.1 \mathrm{M}$ potassium nitrate and starch $0.2 \%(\mathrm{w} / \mathrm{v})$, as nitrogen and carbon sources, respectively; medium B contained $1 \%$ ammonium chloride and starch $0.2 \%(\mathrm{w} / \mathrm{v})$; and medium C contained $1 \%(\mathrm{w} / \mathrm{v})$ ammonium acetate, source of both carbon and nitrogen, and supplemented with $0.2 \%(\mathrm{w} / \mathrm{v})$ soluble starch (adding a previously filter-sterilised starch stock solution). The clarified medium used for further assays was obtained by harvesting cells by centrifugation at $10,000 \mathrm{rpm}$ for $30 \mathrm{~min}$ at $4^{\circ} \mathrm{C}$, at least two times, until no suspension of particles was observed.

\subsection{Determination of Degrading Activity}

The activities were routinely assayed by the iodine binding assay, in $20 \mathrm{mM}$ Tris- $\mathrm{HCl}$ buffer $\mathrm{pH} 7.5$, at $40^{\circ} \mathrm{C}, 3 \mathrm{M} \mathrm{NaCl}$ (activity buffer). The adequate starch concentration in the reaction mixture was adjusted with potato-soluble starch (Sigma) and terminated it by cooling in ice. Colour appeared by the addition of iodine solution $[4 \%$ potassium iodide (w/v), $1.25 \%$ iodine $(\mathrm{w} / \mathrm{v})]$ and the loss of starch was determined spectrophotometrically at $600 \mathrm{~nm}$.

One unit of activity was the amount of protein that hydrolysed $1 \mathrm{mg}$ of starch in $1 \mathrm{~min}$ [12].

The activity was also measured by the dinitrosalicylic acid method [13] in order to determine the release of reducing end sugars.

The reaction was kept at the temperatures tested in a thermostatic bath and stopped in ice. The dinitrosalicylic acid reagent $(100 \mu \mathrm{L})$ was added to the samples and this mixture was heated at $100^{\circ} \mathrm{C}$ in a boiling bath for $10 \mathrm{~min}$. The development of colour was measured spectrophotometrically at $540 \mathrm{~nm}$. One unit of activity was defined as the amount of protein, which produced $1 \mu \mathrm{mol}$ of reducing ends in 1 min. Maltose was used for a standard curve. All assays were performed, at least, in duplicate and average values obtained.

\subsection{Cyclodextrin Glycosyltransferase Activity Assay}

The cyclisation activity was determined using different dyes: methyl orange, phenolphthalein and bromocresol green. The production of cyclodextrins was analysed spectrophotometrically by the absorbance decrease at $490 \mathrm{~nm}$ in the case of a-CD and $552 \mathrm{~nm}$ for b-CD, and by the increase in absorbance at $630 \mathrm{~nm}$ for c-CD. The reaction mixture contained potato starch solution $1 \%(\mathrm{w} / \mathrm{v})$ in $0.1 \mathrm{M}$ Bis-Tris propane, $\mathrm{pH}$ $7.0,1.5 \mathrm{M} \mathrm{NaCl}$ buffer (buffer $\mathrm{C}$ ). One unit of cyclisation activity $(U)$ is defined as the amount of enzyme that produces $1 \mathrm{Imol}$ of $\mathrm{a}-\mathrm{-}, \mathrm{b}-$ or $\mathrm{c}-\mathrm{CD}$, as described by Bautista et al. [6].

\subsection{Enzymes Isolation}

The supernatant from $100 \mathrm{~mL}$ culture was passed through a starch column prepared with insoluble starch packed in a $2.5 \times 10 \mathrm{~cm}$ column. This column was intensively washed with $3 \mathrm{M}$ $\mathrm{NaCl} 0.02 \mathrm{M}$ Tris- $\mathrm{HCl}$ pH 8.0 buffer, as previously described in Perez-Pomares et al (2009). The washoff was collected and the column intensively washed in $20 \mathrm{mM}$ Tris- $\mathrm{HCl}$ buffer $3 \mathrm{M} \mathrm{NaCl}$ (buffer $A$ ) until no activity at all was observed in the fractions obtained. The elution of the proteins retained in the column was performed by using an increasing concentration of maltose, with a gradient of maltose from 0 to $0.2 \mathrm{M}$ for both media. A discontinuous gradient of crescent concentrations of maltose was used for better isolation of the different enzymes and used for further studies. Amylase activity was tested in all the fractions and pooled the more active, Sephacryl S-300 and a Sepharose 4-B gel filtration column that also served to determine its molecular weight. Protein concentration was determined by the Bradford method [14].

The active fractions were concentrated and desalted to a final volume of $500 \mu \mathrm{L}$ by ultrafiltration in an Amicon concentrating unit using a 10,000-MW cut-off membrane, and the enzyme was analysed by SDS-PAGE for purity and subunit molecular weight.

\subsection{Analysis of Reaction Products}

Thin-layer chromatography (TLC) was used in order to analyse the products of the different amylolytic activities. Each purified enzyme was 
incubated overnight in the reaction mixture, as described previously, and spotted in silica gel plates. Each plate was developed with solvent mixtures containing different proportions of isopropanol-ethyl acetate-water. Standard $50 \mathrm{mM}$ or $1 \%$ solutions of the carbohydrates used as substrates were also included in the plates.

The oligosaccharides were detected by spraying $1 \%$ diphenylamine, dissolved in acetone containing $10 \%$ phosphoric acid to the TLC plate, and heated at $160^{\circ} \mathrm{C}$ for $10 \mathrm{~min}$ as described by Kobayashi et al. [8].

Besides, the hydrolysis products of the amylolytic enzymes were analysed by gel filtration in a 2.5 $\times 30 \mathrm{~cm}$ Sephadex G-100 column. The lower molecular weight products were further analysed by high-performance liquid chromatography (HPLC) in a carbohydrate column (4.6.250 mm Waters, Milford, Mass.) in $50 \mathrm{mM}$ phosphate

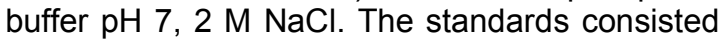
of maltose, maltotrioside, and maltohexaoxide prepared in concentrations of $1 \mathrm{mM}$ in the same conditions as the reaction products.

\subsection{Effect of Salt Concentration, $\mathrm{pH}$ and Temperature}

The effect of salt concentration on enzyme activity was tested by measuring the activity at $40^{\circ} \mathrm{C}$ in $20 \mathrm{mM}$ Tris- $\mathrm{HCl}, \mathrm{pH} 7.3$, buffers containing different $\mathrm{NaCl}$ concentrations. For each salt concentration, starch concentration varied from 0.02 to $0.2 \%(\mathrm{w} / \mathrm{v})$.

The stability of the amylase at different salt concentrations $(0 \mathrm{M}, 2 \mathrm{M}$ and $3 \mathrm{M})$ was determined by incubating the enzyme in buffers containing the studied salt concentration and measuring the activity of aliquots at different times.

For the study of $\mathrm{pH}$, different buffers were used: $0.2 \mathrm{M}$ citric acid/ phosphate for $\mathrm{pH}$ ranging from 4.5 to $7,0.2 \mathrm{M}$ Tris- $\mathrm{HCl}$ buffers for $\mathrm{pH}$ ranging from 7 to 9 , and $0.2 \mathrm{M} \mathrm{CHES}$ buffers for $\mathrm{pH}$ ranging from 9 to 10 . Each of them contained 3 $\mathrm{M} \mathrm{NaCl}$. The $\mathrm{pH}$ was checked after each reaction but showed no changes with respect to the initial values. The assays to study the dependence of temperature were carried out in $0.2 \mathrm{M}$ phosphate buffer, $\mathrm{pH} 7.5,3 \mathrm{M} \mathrm{NaCl}$, at different temperatures. For each $\mathrm{pH}$ and temperature, starch concentrations varied from 0.5 to 5 $\mathrm{mg} / \mathrm{mL}$.

\subsection{Inhibition by Maltose}

The inhibition by maltose was tested by measuring the activity at $40^{\circ} \mathrm{C}$ in $20 \mathrm{mM}$ Tris$\mathrm{HCl}, \mathrm{pH} 7.3$, buffers containing different $\mathrm{NaCl}$ concentrations. For each maltose concentration, starch concentration varied from $0.67 \mathrm{mg} / \mathrm{mL}$ to $6.7 \mathrm{mg} / \mathrm{mL}$ of starch; and maltose concentrations tested were; $0,0.075 \mathrm{M}, 0.15,0.25$ and $0.35 \mathrm{M}$.

\subsection{Data Processing}

Reciprocal initial velocities were plotted versus reciprocal substrate concentrations. All plots were linear. Initial velocities (v) obtained at each salt concentration, $\mathrm{pH}$, or temperature, respectively, by varying the substrate concentration (S), were fitted to MichaelisMenten equation to obtain maximum velocity $(\mathrm{V})$, the Michaelis constant $(\mathrm{K})$ for the substrate, and the apparent first-order constant for the interaction of enzyme and substrate (V/K). SigmaPlot program (Jandel Scientific, v. 1.02) along with the algorithm of Marquardt-Levenberg were applied. Same processing was followed with data from each salt concentration and for each maltose concentration. In the study of the inhibition of the enzyme with maltose, the inhibition constant was determined by adjusting the data to the competitive inhibition reaction.

Data from the stability studies were fitted as a logarithm of the residual activity versus time for each salt concentration, $\mathrm{pH}$, or temperature studied.

The half-life and the pseudo-first-order constant for the denaturing process were determined from the slope of the straight lines obtained. [15]

\subsection{Peptide Sequencing by Mass Spectrometry (ESI-MS/MS)}

Coomassie-stained protein bands were excised from the gel, in-gel digested with trypsin (sequencing grade porcine trypsin, Pro- mega), according to the University of Alicante Mass Spectrometry Facility in-gel digestion procedure, and subjected to ESI-MS/ MS. Analysis was performed in a Q-Tof (Micromass) coupled to a CapLC (Waters) chromatographic system. The tryptic peptides were purified using a Waters Opti-Pak C18 trap column. The trapped peptides were eluted using a water/acetonitrile $0.1 \%(\mathrm{v} / \mathrm{v})$ formic acid gradient and separated by a $75 \mathrm{~mL}$ internal diameter, capillary column home-pack with C18 silica. Data were acquired in data- 
dependent mode and multiplied charged ions were subjected to MS/MS experiments. The MS/MS spectra were processed using MAXENT 3 (Micromass) and manually sequenced using the PEPSEQ program (Micromass). The primary sequence was analysed using the BLAST database (http://www.ncbi.nih.gov/BLAST).

\section{RESULTS}

\subsection{Amylolytic Activities Excreted into Different Media}

For each medium, containing nitrate $A$, ammonium chloride $\mathrm{B}$, and ammonium acetate C, different total starch degrading activity was obtained. This can be due to the amount and the concentration of the enzymes excreted or also due to the different set of enzymes secreted. However, nearly no growth was observed in the ammonium chloride containing Medium B. The maximal weight of cells grown in medium $A$ was $2.5 \pm 0.5 \mathrm{~g}$ wet cells per $100 \mathrm{~mL}$ culture, similar to that found in medium $\mathrm{C}, 2.2 \pm 0.5 \mathrm{~g}$. This was much higher than that found for medium $B$, i.e., $0.5 \pm 0.15 \mathrm{~g}$ per $100 \mathrm{~mL}$ culture. However, inspite of this residual growth, amylolytic activities were detected in it. These activities, compared with that found in Medium A using a starch column, as previously described, with a gradient from 0 to $0.2 \mathrm{M}$ maltose, (Fig. 1A).
Medium C was used exclusively as growth and amylolytic activity control, since previous studies had already been reported, including the full characterisation of two external amylolytic enzymes, viz., a-amylase [5] and cyclodextrin glycosyltransferase [6]. Moreover, medium C contained nothing but two different carbon sources (acetate and starch). In order to study the exclusive use of starch as a carbon source, the present study focused on the starch degrading enzymes excreted in media $A$ and $B$, where the set of enzymes permitted full usage of starch as an exclusive carbon source.

The results in Fig. 1B again display a set of different amylolytic activities excreted. There were at least six main activities named as amyl, to amyVI. The little peak at approximately $5 \mathrm{mM}$ maltose was not marked. The complexity in the number of the enzymes implied led us to pay attention only to the more prominent activities. The growth of the organism in ammonium chloride produced general enzymes that eluted at higher maltose concentration, producing practically undetected activity at a concentration higher than $0.2 \mathrm{M}$ maltose. The chromatography produced partially purified samples (Table 1), with a high purification factor, and further purified as previously described. The last purification step also served to estimate their molecular weight.

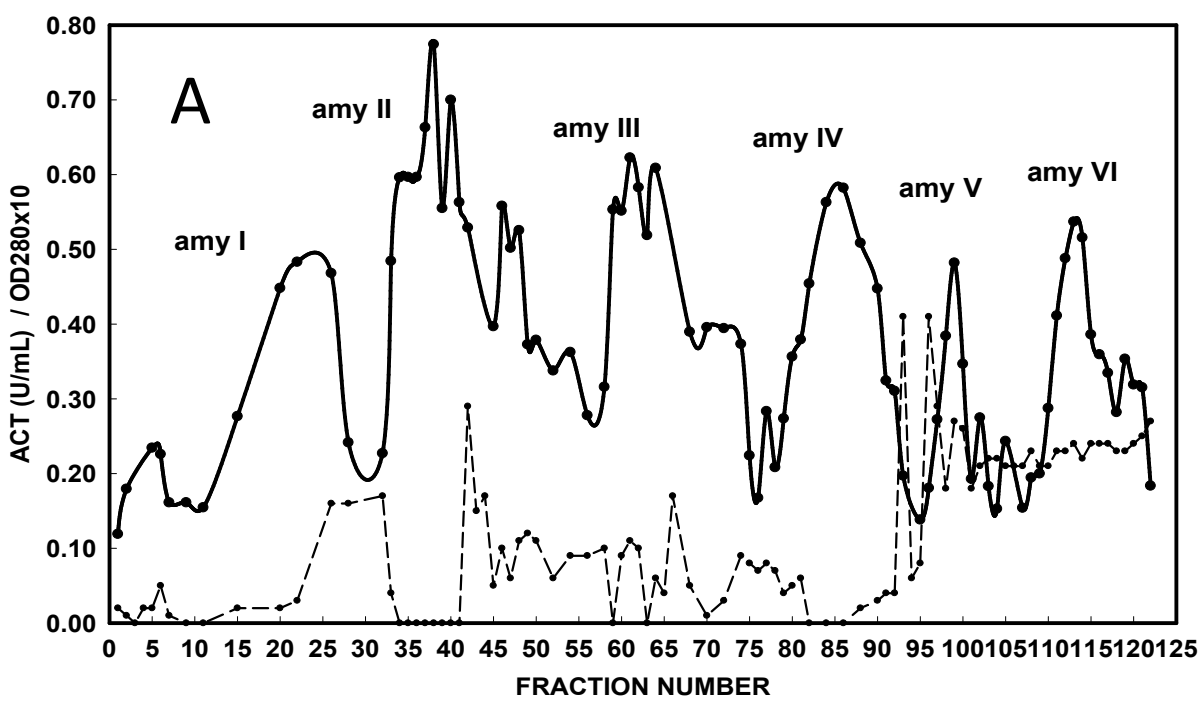

Fig. 1A. Chromatography of the clarified external medium from a culture of $\boldsymbol{H}$. mediterranei in medium A, performed in a small column filled with insoluble starch. Proteins retained were eluted with buffer $A$, containing increasing concentrations of maltose: $5,10,20,50,75,100$ and $200 \mathrm{mM}$ maltose, which corresponds to the fractions from 1 to 29,30 to 54,55 to 74,75 to 95 , 96 to 108 and from 109 to 125 , respectively. The dashed line represented the protein content, as absorbance at $280 \mathrm{~nm}$ 


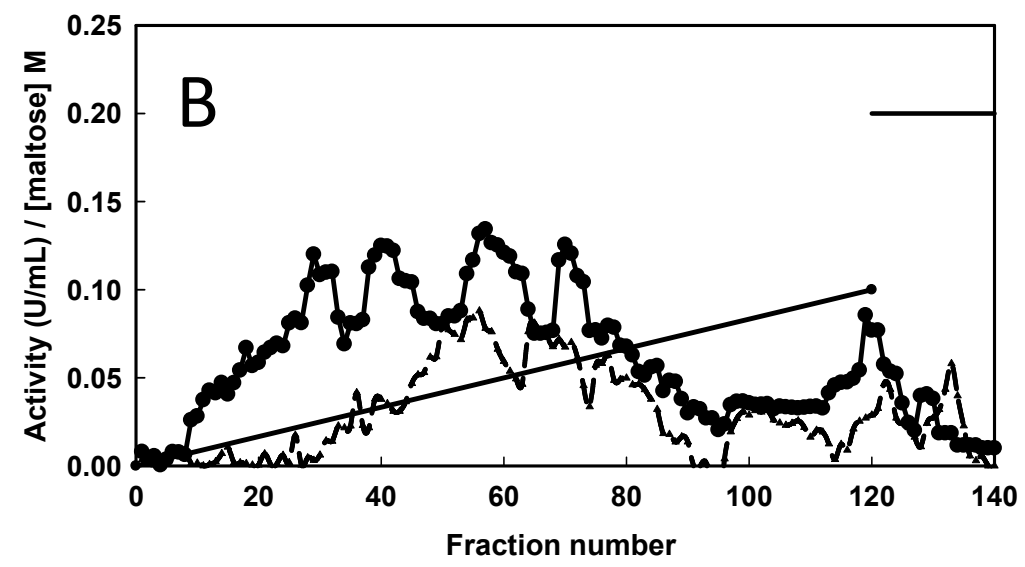

Fig. 1B. Amylolytic activities isolated as in Fig. 1A, but using a linear gradient from 0 to $0.1 \mathrm{M}$ maltose and a final elution with $0.2 \mathrm{M}$ maltose. The circles $(\bullet)$ united with a continuous line corresponds to clarified external medium of cells grown with potassium nitrate as nitrogen source and the up triangles $(\Delta)$ and dashed line, the same but with ammonium chloride as a nitrogen source. For all the fractions collected, the volume was $3 \mathrm{~mL}$

The obtained molecular masses summarised in Table 2, depended on the matrix gel, dextrose gels Sephacryl S300 and Sepharose 4B, used, and so They are considered only as estimated masses. The chemical composition of the chromatographic polymer used, its carbohydrate related nature, may be leading, in general, to affinity interactions enzyme-bed polymer, and consequently, to underestimated molecular weights, lower than those obtained by SDSPAGE analysis (Fig. 7). Attending to these values (Table 2), and position of the main bands (Fig. 7), corresponding to the amylolytic enzymes, all of them should be considered as monomeric enzymes.

Once purified, these purified samples were used in the further studies.

\subsection{Maltose Inhibition and Kinetic Parameters}

Data for the interactions between maltose and the starch degrading enzymes displayed competitive patterns for Lineweaver-Burk plot, all of them were similar to amyll as shown in Fig. 2.

Table 2 summarises the kinetic parameters from the equation for competitive inhibition. The Michaelis-Menten parameters, calculated by fitting the data to inhibition equations: $\mathrm{V}$ and $\mathrm{K}$, were very similar for all activities. However, maltose did not exhibit any significant inhibitory effect for amyl nor amyV. Meanwhile, in the conditions tested, the other activities had a very similar behaviour with $\mathrm{Ki}$ values in the same range (values, from 360 to $530 \mathrm{mM}$, higher than the maltose concentration necessary to completely elute the starch hydrolases from the column). Consequently, maltose interactions with the starch and/or enzymes, may not be necessarily related to the catalytic core of these enzymes. Moreover, the different behaviour of these activities regarding inhibition by maltose was indicative of concurrence of several enzymes implicated in starch degradation and processing.

\subsection{Salt, pH and Temperature Requirements}

Regarding salt concentration and activity and stability, dialysis of samples in $0 \mathrm{M}$ salts resulted in irreversible loose of activity of the enzymes. Although all of them displayed a marked halophilic character, both for activity and stability, the dependence of the kinetic parameters obtained for each salt concentration displayed quite different patterns (Fig. 3). In fact, salt concentration affected $\mathrm{V}$ for amyl increasing its values to a plateau at 3 to $4 \mathrm{M} \mathrm{NaCl}$, and the same with $V / K$, due to the little changes observed in $\mathrm{K}$ values (related to the affinity of theenzyme with starch). The other degrading activities suffered changes in both $\mathrm{V}$ and $\mathrm{K}$, but led to a final increase in $\mathrm{V} / \mathrm{K}$, related to their catalytic efficacy in degrading starch, except for amyV, the only degrading activity whose $\mathrm{V} / \mathrm{K}$ 
decreased a little as salt concentration increased, with maximal activity at very low salt concentration. However, it was able to maintain its activity and $\mathrm{V} / \mathrm{K}$ with increasing salt concentration until $3 \mathrm{M} \mathrm{NaCl}$.

The study of activities with $\mathrm{pH}$ also displayed differences between them. As shown in Fig. 4 profiles found in plots $\mathrm{Vmax}$ versus $\mathrm{pH}$ may be related to the acid-base behaviour of the residues implied in the reaction, that in the "acidic side of the profile" that should be deprotonated, and that in the basic side, protonated for an active enzyme. Except for amyll, activated at $\mathrm{pH} 5$, the other activities started at $\mathrm{pH} 6$, and decayed at $\mathrm{pH} 9$, except amyll, which decayed at $\mathrm{pH} 10$. Both amyV and amyVI, decayed at $\mathrm{pH} 8$.

Table 1. Purification of the excreted external amylolytic activities from $\boldsymbol{H}$. mediterranei grown in a medium containing $0.1 \mathrm{M}$ potassium nitrate and $0.2 \%$ starch. Yield values were estimated considering that a volume of $3 \mathrm{~mL}$ of sample from starch column was applied to Sephacryl S300

\begin{tabular}{|c|c|c|c|c|c|c|c|}
\hline & & $\begin{array}{l}\text { Volume } \\
\text { (ml) }\end{array}$ & $\begin{array}{l}\text { Activity } \\
\text { (U/ml) }\end{array}$ & yield(\%) & $\begin{array}{l}\text { protein conc } \\
(\mathrm{mg} / \mathrm{ml})\end{array}$ & $\begin{array}{l}\text { specific } \\
\text { activity } \\
(\mathrm{U} / \mathrm{mg})\end{array}$ & $\begin{array}{l}\text { Purification } \\
\text { factor }\end{array}$ \\
\hline $\begin{array}{l}\text { Clarified } \\
\text { external } \\
\text { nedium }\end{array}$ & & 100 & 1.8 & 100 & 0,25 & 7.2 & 1 \\
\hline \multirow[t]{2}{*}{ amyl } & $\begin{array}{l}\text { Starch } \\
\text { column }\end{array}$ & 21 & 0.42 & 4,9 & $41 \cdot 10^{-3}$ & 10.2 & 1.4 \\
\hline & $\begin{array}{l}\text { Sephacryl } \\
\text {-S300 }\end{array}$ & 14 & 0,035 & 39 & $1.0 \cdot 10^{-3}$ & 35 & 4,9 \\
\hline \multirow[t]{2}{*}{ amyll } & $\begin{array}{l}\text { Starch } \\
\text { column }\end{array}$ & 18 & 1.10 & 11 & $29 \cdot 10^{-3}$ & 37.9 & 5.3 \\
\hline & $\begin{array}{l}\text { Sephacryl } \\
\text {-S300 }\end{array}$ & 6 & 0.086 & 28 & $2.0 \cdot 10^{-3}$ & 43 & 6.0 \\
\hline \multirow[t]{2}{*}{ amyllI } & $\begin{array}{l}\text { Starch } \\
\text { column }\end{array}$ & 9 & 0.80 & 4 & $19 \cdot 10^{-3}$ & 42.1 & 5.8 \\
\hline & $\begin{array}{l}\text { Sephacryl } \\
\text {-S300 }\end{array}$ & 16 & 0.11 & 73 & $1.8 \cdot 10^{-3}$ & 61.1 & 8.5 \\
\hline \multirow[t]{2}{*}{ amylV } & $\begin{array}{l}\text { Starch } \\
\text { column }\end{array}$ & 18 & 0.99 & 9.9 & $16 \cdot 10^{-3}$ & 61.9 & 8.6 \\
\hline & $\begin{array}{l}\text { Sephacryl } \\
-S 300\end{array}$ & 12 & 0.12 & 48 & $0,83 \cdot 10^{-3}$ & 144.5 & 20 \\
\hline \multirow[t]{2}{*}{ amyV } & $\begin{array}{l}\text { Starch } \\
\text { column }\end{array}$ & 15 & 0.84 & 7 & $61 \cdot 10^{-3}$ & 13.8 & 1.9 \\
\hline & $\begin{array}{l}\text { Sephacryl } \\
\text {-S300 }\end{array}$ & 6 & 0.114 & 27 & $5.0 \cdot 10^{-3}$ & 22.8 & 3.2 \\
\hline \multirow[t]{2}{*}{ amyVI } & $\begin{array}{l}\text { Starch } \\
\text { column }\end{array}$ & 15 & 0.78 & 4,9 & 0.09 & 8.6 & 1.2 \\
\hline & $\begin{array}{l}\text { Sephacryl } \\
\text {-S300 }\end{array}$ & 10 & 0.07 & 30 & $7.2 \cdot 10^{-3}$ & 9.7 & 1.4 \\
\hline
\end{tabular}

Table 2. Estimated molecular weights for the excreted amylase activities by $\boldsymbol{H}$. mediterranei, by gel filtration in both, Sephacryl S300 and sepharose 4B

\begin{tabular}{llll}
\hline & Sephacryl S300 & Sepharose 4B & Average Mr \\
\hline amyl & $27 \pm 4 \mathrm{kDa}$ & $40 \pm 9 \mathrm{kDa}$ & $34 \pm 7 \mathrm{kDa}$ \\
amyll & $19 \pm 3 \mathrm{kDa}$ & $29 \pm 7 \mathrm{kDa}$ & $24 \pm 5 \mathrm{kDa}$ \\
amylll & $23 \pm 4 \mathrm{kDa}$ & $20 \pm 6 \mathrm{kDa}$ & $22 \pm 5 \mathrm{kDa}$ \\
amylV & $16 \pm 3 \mathrm{kDa}$ & $43 \pm 9 \mathrm{kDa}$ & $30 \pm 6 \mathrm{kDa}$ \\
amyV & $19 \pm 3 \mathrm{kDa}$ & $43 \pm 9 \mathrm{kDa}$ & $31 \pm 6 \mathrm{kDa}$ \\
amyVI & $16 \pm 3 \mathrm{kDa}$ & $17 \pm 5 \mathrm{kDa}$ & $17 \pm 4 \mathrm{kDa}$ \\
\hline
\end{tabular}




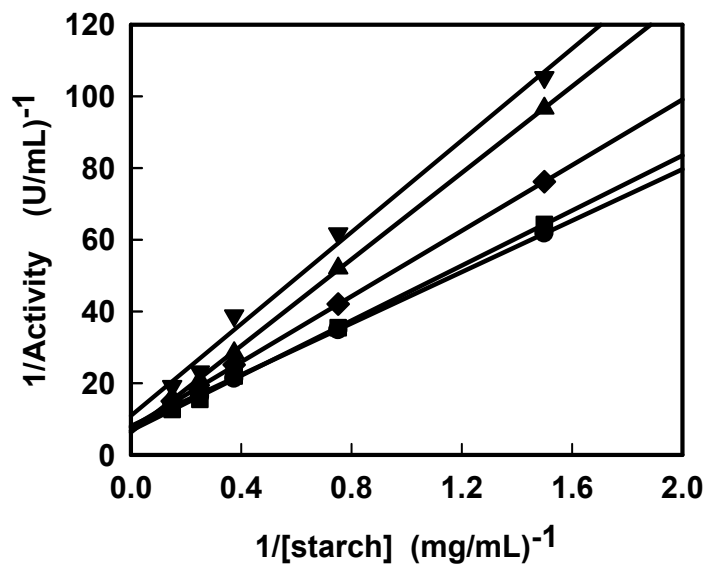

Fig. 2. Maltose inhibition pattern obtained for the hydrolysis of starch by amyll. Symbols $(\bullet)$ OM maltose; ( $\square$ ) $0.075 \mathrm{M}$ maltose; ( $\bullet$ ) $0.15 \mathrm{M}$ maltose; ( $\triangle$ ) $0.25 \mathrm{M}$ maltose; $(\nabla)$ ) $0.35 \mathrm{M}$ maltose

Table 3. Kinetic parameters and the inhibition constant Ki for maltose as a competitive inhibitor of the hydrolysis of starch catalyzed by amyl, II, III, IV, V and VI

\begin{tabular}{llll}
\hline Kinetic parameters & $\mathbf{V}(\mathbf{U} / \mathbf{m L})$ & $\mathbf{K}(\mathbf{m g} / \mathbf{m L})$ & $\mathbf{K i ~} \mathbf{~ M}$ \\
\hline amyl & $0.75 \pm 0.14$ & $5,3 \pm 1.7$ & - \\
amyll & $1.26 \pm 0.10$ & $4.1 \pm 0.7$ & $360 \pm 7$ \\
amyllI & $0.98 \pm 0.10$ & $3.3 \pm 0.8$ & $470 \pm 16$ \\
amylV & $1.7 \pm 0.3$ & $5.0 \pm 1.5$ & $530 \pm 19$ \\
amyV & $0.47 \pm 0.05$ & $5.2 \pm 1.1$ & - \\
amyVI & $0.82 \pm 0.08$ & $3.9 \pm 0.8$ & $357 \pm 9$ \\
\hline
\end{tabular}
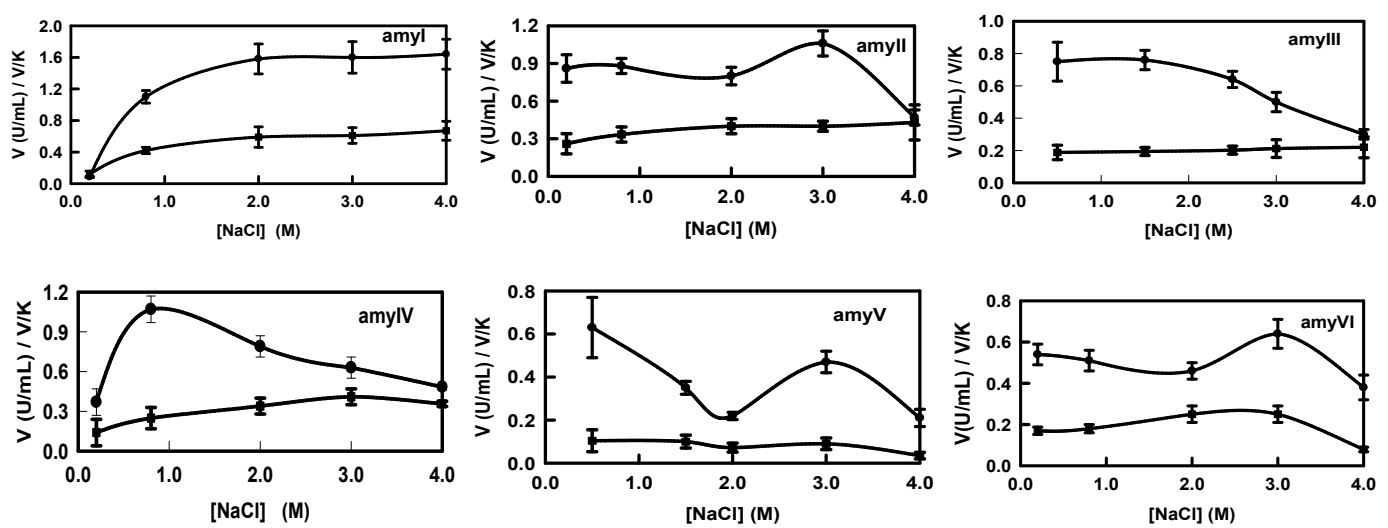

Fig. 3. Salt concentration $(\mathrm{NaCl})$ effect on the kinetic parameters corresponding to the hydrolysis of starch catalyzed by amyl, II, III, IV, V and VI, respectively. Data were fitted to

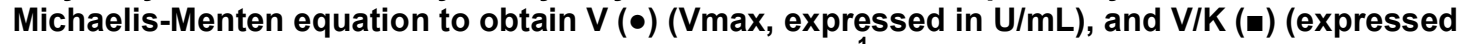
in $\left.\mathrm{U} / \mathrm{mL} \cdot(\mathrm{mg} / \mathrm{mL})^{-1}\right)$

Finally, their behaviour with temperature have been displayed in Fig. 5. The results presented differences in the patterns obtained: amyllI and amy $\mathrm{V}$ were fully active at $50^{\circ} \mathrm{C}$, and the other at $40^{\circ} \mathrm{C}$, and in the other side, amylll still highly active at $70^{\circ} \mathrm{C}$, instead of $60^{\circ} \mathrm{C}$ for the other ones. It may be attributed certain thermophilic character to amylll activity, a feature that has been frequently reported for enzymes obtained from halophilic organisms. 


\subsection{Analysis of Products}

The products obtained were analysed by different methods, mainly by thin layer chromatography (TLC). The study of these products by HPLC did not yield in all the cases clear chromatograms, which resolution was not enough to consider them significant. The other technique used was thin layer chromatography. All TLC plates developed for these products showed not a single product but a mixture of them. In Fig. 6, lane I, the products of amyl, mainly maltose, similar to amyll, are displayed, which produced a mixture of maltose and glucose. The products of amylll were mainly maltotriose, maltohexose and larger saccharides. AmylV only produced larger (counted in "glucose units") saccharides and amyV and amyVI also produced maltohexose (or similar size). Calculation of the average sizes of the pieces produced by the enzymes, assuming the production of molecules with reducing ends from starch (non-reducing ends containing molecule) also offered an approximation of the kind of components of the final reaction mixture. Assuming homogeneity, the average size of the saccharides produced by amyl was 2.6 \pm 0.6 glucose units, similar to $2.4 \pm 0.3$ for amyll. For amyllI, amylV, amyV and amyVI, the values were $29 \pm 10$ glucose units, $6.6 \pm 1.5$ glucose units, $50 \pm 10$ glucose units and $23 \pm 5$ glucose units, respectively, coherent with a mixture of saccharides of different size observable in the thin layer chromatogram (Fig. 6), probably due to a random and complex degradation of the starch. The activities of amy I, II, IV produced mainly low molecular weight oligosaccharides; meanwhile amy III, V, and VI produced larger carbohydrates, This was not in contradiction with the ability of amy I and amy II, to produce glucose and maltose, while the other activities would mainly be devoted to obtain larger saccharides.
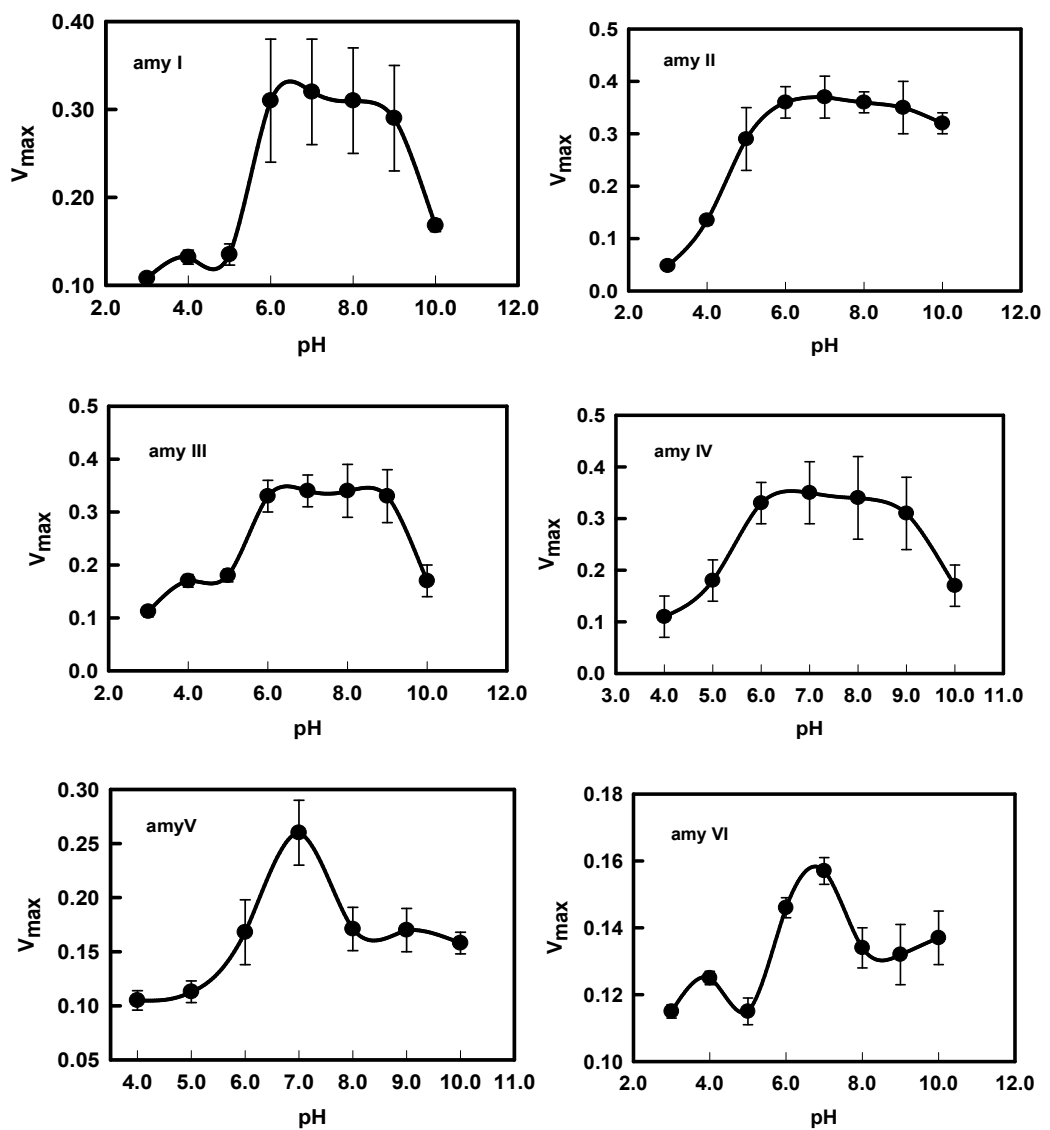

Fig. 4. Effect of $\mathrm{pH}$ on the kinetic parameters determined at $40^{\circ} \mathrm{C}$ by varying starch concentration for each pH by amyl, II, III, IV, V and VI, respectively 

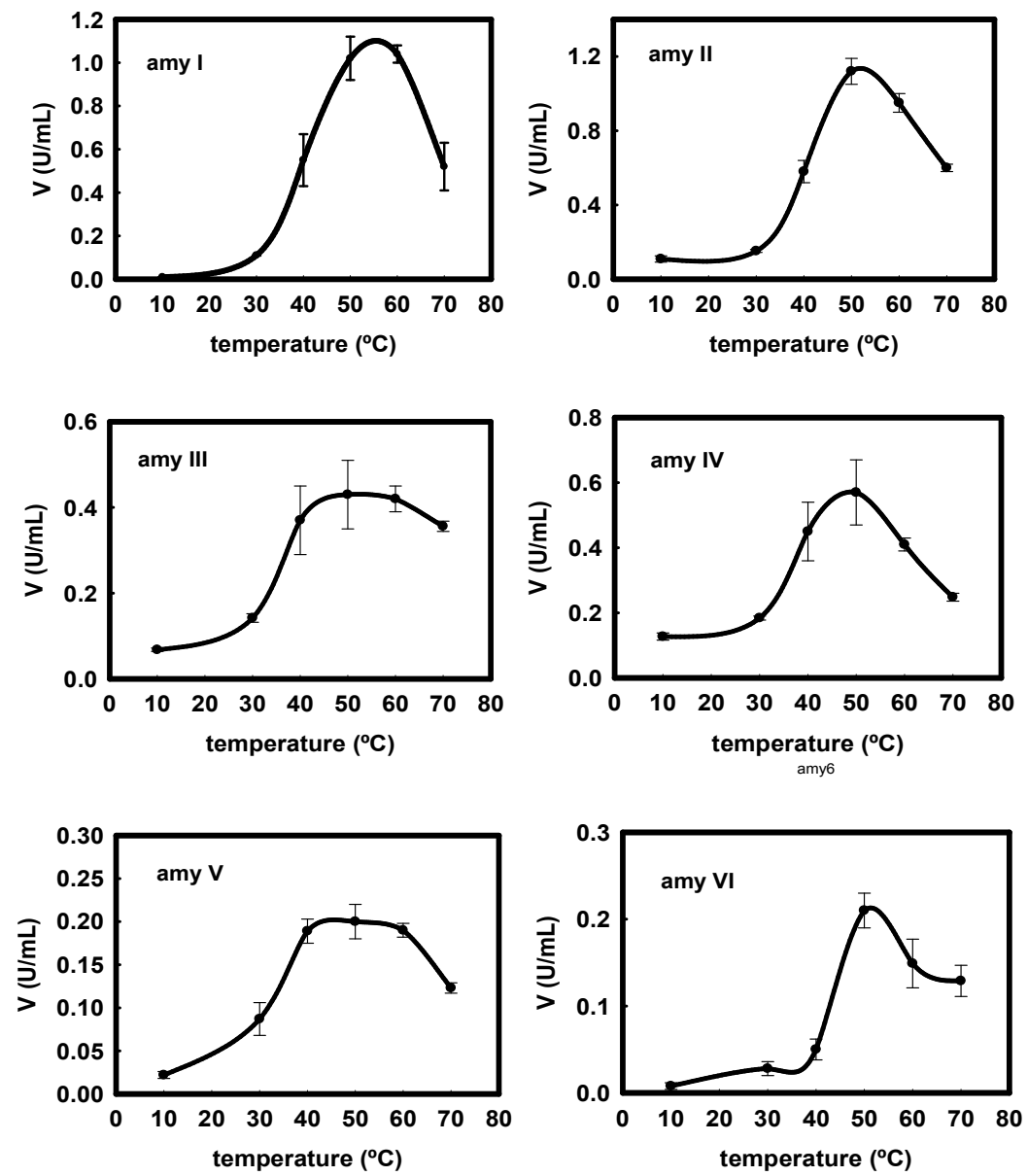

Fig. 5. Effect of temperature on the kinetic parameter Vmax, determined as described in "materials and methods" at temperatures from $10^{\circ} \mathrm{C}$ to $70^{\circ} \mathrm{C}$ for amyl, II, III, IV, V and VI respectively

An attempt was made to assign these activities to the already found genes that encode for amylolytic activities into Haloferax mediterranei complete sequenced genome disposable in NCBI databases. This has been exposed in Table 4. These genes include the cyclodextrin glucanotransferase, already fully characterised and described by Bautista et al. [6].

To achieve this aim, the most prominent bands in these polyacrylamide gels were subjected to mass-spectrophotometry studies, but none of them yielded reliable results (Fig. 7). The peptides obtained by trypsin digestion of these selected SDS-PAGE bands, did not match significantly with already reported hydrolysing enzymes, except those from cultures in ammonium acetate medium, which matched $100 \%$ with cyclodextrin glucanotransferase sequence, (Table 4). This finding was in consistent with the lack of cyclodextrin glucanotransferase specific activity in all the samples from cultures in potassium nitrate medium.

This method obtained the peptides performing a random calculation of molecular weights accordingly with those already found in databases. These randomly obtained peptides may not be found in these databases as pertaining to carbohydrate hydrolyzing enzymes, and further work is still undone in peptide assignation to each gene, or even not all genes have been already found. More work would be necessary to further understand the published genomes, thus reflecting their enormous complexity, especially their proteomic aspect. 


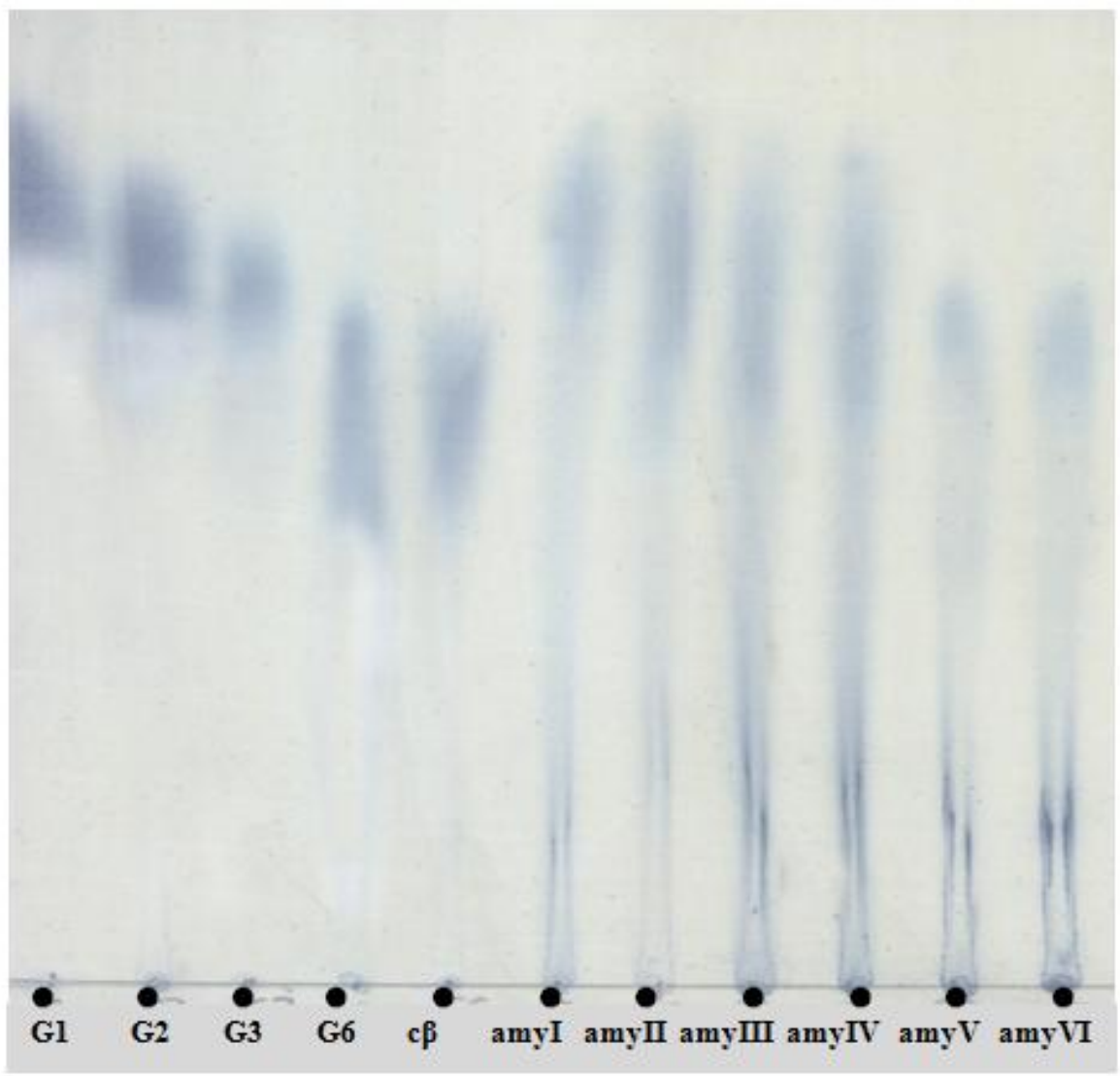

Fig. 6. Thin layer chromatography plate developed with a mixture of isopropanol, ethyl acetate and water. Standards lanes: G1 glucose, G2 maltose, G3 maltotriose, G6 maltohexose, c $\beta$ ciclodextrine; sample lanes: amyl to amyVI, corresponding to the reactions with these activities, respectively

Table 4. Genes assigned to amylolytic activities, found into the $H$. mediterranei complete genome disposable in NCBI databases, marked in bold the cyclodextrin glucanotransferase [6]

\begin{tabular}{llllll}
\hline Gene name & Entry name & Protein name & Aa & Mr kDa & pl \\
\hline $\begin{array}{l}\text { amy1 HFX_0533 } \\
\text { C439_07790 }\end{array}$ & I3R200_HALMT & Alpha amylase/glucosidase & 701 & 78.2904 & 4.17 \\
\hline $\begin{array}{l}\text { Cgt } \\
\text { amyP1HFX_0535 }\end{array}$ & Q53I75_HALME & Cyclodextrin glucanotransferase & 713 & 78.5994 & 4.19 \\
C439_07780 & I3R2_HALMT & & & & \\
\hline $\begin{array}{l}\text { amy3 HFX_1044 } \\
\text { C439_05260 }\end{array}$ & I3R202_HALMT & Alpha glucosidase & 599 & 69.5004 & 4.32 \\
\hline $\begin{array}{l}\text { amy4 HFX_1802 } \\
\text { C439_01492 }\end{array}$ & I3R5J6_HALMT & $\begin{array}{l}\text { Glucan 1,4-alpha-maltohydrolase } \\
\text { lalpha-glucosidase }\end{array}$ & 698 & 77.207 & 4.28 \\
\hline $\begin{array}{l}\text { amy5 HFX_1803 } \\
\text { C439_01487 }\end{array}$ & I3R5J7_HALMT & Glucoamylase / glycosyl hydrolase & 1511 & 166.6422 & 4.56 \\
\hline $\begin{array}{l}\text { amy2 HFX_1803 } \\
\text { C439_01487 }\end{array}$ & I3R5J7_HALMT & $\begin{array}{l}\text { Glucan 1,4-alpha-glucosidase / } \\
\text { glycosyl hydrolase }\end{array}$ & 673 & 74.2576 & 4.26 \\
\hline $\begin{array}{l}\text { HFX_1801 } \\
\text { C439_01497 }\end{array}$ & I3R5J5_HALMT & Hypotetical protein & 879 & 98.5281 & 4.20 \\
\hline
\end{tabular}




\section{DISCUSSION, CONCLUSIONS AND FINAL REMARKS}

The purification schedule was a little different to that routinely followed for other halophilic enzymes, already discussed in previous reports [5], [6] but was quite similar to that used to isolate glycolytic enzymes in cell cytoplasm [10]. Moreover, the starch column was chosen to select only those enzymes that interact more closely and specifically, with starch (being able to stick to it actually), and on the other hand, are able to respond to the presence of maltose, one of the possible oligosaccharides produced in the enzymatic degradation of starch. Since the different activity peaks found in the starch column chromatograms represented the interactions between complex molecules, starch and the enzymes, as well as the interactions with maltose, each peak observed not due to different enzymes but due to the different ways of their interation, corresponding to the possible different conformations or points of interaction in the enzyme. Further analysis of these activities showed deep differences between them, leading to confirm the presence of different enzymes.

Although all of them behaved as typical halophilic enzymes, the effect of salt concentration on the kinetic parameters was illustrative of the variety of ways, strategies, halophilic organisms possess to affront or profit the high salinity in their natural environments. Curiously, the patterns for amy II to amy $\mathrm{V}$ were anyhow similar to that reported for the glutamate dehydrogenase from the extreme halophilic bacteria Salinibacterruber[16], that also displayed high activity both at a relatively low and a very high salt concentration.

In addition, the effects of $\mathrm{pH}$ on these parameters were not same for all the amylolytic activities, indicating that protonationdeprotonation of the amino acidic residues implied in the reaction occurred at different $\mathrm{pH}$ and consequently there were differences in the chemical mechanism they followed. In fact, the products obtained were different for each of them: amyl, II. IV would be essential to produce glucose and maltose, and amyllI, V, and VI would degrade starch more randomly, producing larger saccharides. This is worthy to mention that the production of amylV, $\mathrm{V}$ and $\mathrm{VI}$ of saccharides approaching six large glucose units, proves the high importance of maltohexose for our organism to succeed in its environment, as already discussed by Bautista et al. [6].

Attending to the possible role of these enzymes, as stated in the introduction, the variety of enzymes that may be related to carbohydrate degradation is enormous, making it difficult to assign the different activities found to its correspondent enzyme. To make it even more

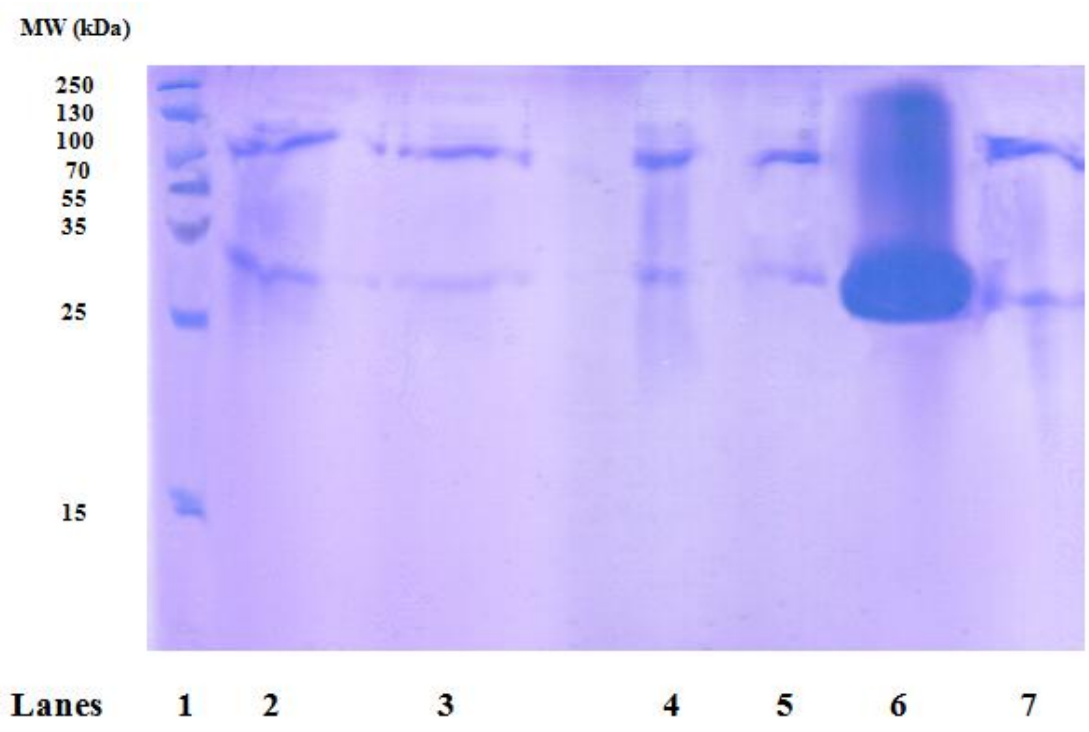

Fig. 7. Patterns of bands obtained by SDS-PAGE for the different purified amylolytic activities described in Table I. Lane 1: Molecular Weight markers, Lane 2 to 7: amyl to amyVI respectively 
complex, available sources of carbon and nitrogen seem to determine their production in microorganisms, such as bacteria Bacillus megaterium [17], Bacillus amyloliquefaciens P001 [18], and Brevibacillus borstelensis R1 [19], fungi as Trichoderma viride BITRS-1001 [20], and also archaeal microorganisms such as Rhodothermus marinus, an extreme thermophilic organism [21]. The same must be applied for the extreme halophilic archaeon Haloferax mediterranei, whose versatility and ability to succeed in a variety of media have made of the adequate object of several studies regarding nitrogen metabolism [2,22]. Its ability to grow with nitrate as a unique nitrogen source enabled us to study how the organism degrades starch as a solely carbon source. This feature clearly demonstrated that the halophilic archaeon possess the needed operative metabolic machinery to get full profit of this source. Since growth in medium C, i.e., ammonium, as a sole nitrogen source, was not successfully achieved by this organism, the assimilation of nitrogen from nitrate must be essential to permit the organism to access to the necessary enzymes to use starch, its only available carbon source.

This adaptation implied the production of a different set of enzymes and also excreted at variable general amylolytic activity in the external media. Both, the number of activities, and the total starch degrading activity were higher in nitrate containing medium than in ammonium one. Since the organism is also known to grow optimally in ammonium sulphate and glucose controlled media (Pire et al. [22]), as well as in ammonium acetate containing medium (Medium C), it may conclude that Haloferax mediterranei is an organism that is unable to use starch optimally when ammonium is the sole nitrogen source, and the use of starch and nitrogen sources is not independent of each other. This ability was probed vital for the organism to grow in each medium.

Moreover, different activities with putative amylolytic activity are reported in the published genome of this halophilic archaeon, Haloferax mediterranei, assigned nearly all of them by computational comparative studies as putative amylolytic genes, corresponding to activities which role has to be related to the abilities to degrade, or modify to be degraded, carbohydrates such as starch. In fact, only one out of these six sequences, the glucotransferase, has been assigned to the external activity characterised by Bautista et al. [6], while others remain uncharacterised. Amylolytic activities excreted strongly depend on, not only carbon sources but also on the nitrogen compounds available in the media.

Nitrogen sources, nitrate and ammonium strongly determine the metabolic pathways working for each set of conditions and influence the yield of production of amylolytic enzymes. Ammonium nitrate and sodium nitrate are the best nitrogen sources for maximum amylase production in microbial enzymes [23], [18]. Besides, different amount of enzyme excreted to the medium, the different set of enzymes implied in each case may differ depending on this nitrogen source. Their isolation and characterisation are necessary for better understanding of the microorganisms, like in this case, extreme halophilic archaea, which deals with the conditions they have to endure and succeed.

In conclusion it can be said that the composition of media strongly determines the set of enzymes employed by the organism to profit starch. Learning more about how the organism gets an optimal profit of starch, implies knowing more about the great variety of amylolytic enzymes present in their genome.

\section{ACKNOWLEDGEMENTS}

This work was supported by project BIO201342921-P from the Spanish Ministry of Economy and Competitiveness

\section{COMPETING INTERESTS}

Authors have declared that no competing interests exist.

\section{REFERENCES}

1. Vihinen $M$, Mantsala $P$. Microbial amylolytic enzymes. Crit Rev Biochem Mol Biol. 1989;24:329-418.

2. Bonete MJ, Camacho M, MartínezEspinosa RM, Esclapez J, Bautista V, Pire C, Zafrilla B, Díaz S, Pérez-Pomares $F$, Llorca $F$. In the light of the haloarchaea metabolism. Communicating Current Research and Educational Topics and Trends in Applied 
Microbiology Ed. A. Méndez-Vilas. 2007;170-183.

3. Groot PC, Bleeker MJ, Pronk JC, Arwert F, Mager WH, Planta RJ, Eriksson AW, Frants RR. The human alpha-amylase multigene family consists of haplotypes with variable numbers of genes. Genomics. 1989;5(1):29-42.

4. van der Maarel MJEC, van der Veen B, Uitdehaag JCM, Leemhuis H, Dijkhuizen L. Properties and applications of starchconverting enzymes of the a-amylase family Journal of Biotechnology. 2002;94: 137-155.

5. Pérez-Pomares $\mathrm{F}$, Bautista $\mathrm{V}$, Ferrer J, Pire C, Marhuenda-Egea FC, Bonete MJ a-Amylase activity from the halophilic archaeon Haloferax mediterranei Extremophiles. 2003;7:299-306.

6. Bautista V, Esclapez J, Pérez-Pomares F, Martínez-Espinosa RM, Camacho M, Bonete MJ. Cyclodextrin glycosyltransferase: A key enzyme in the assimilation of starch by the halophilic archaeon Haloferax mediterranei Extremophiles. 2012;16(1):147-159.

7. Good WA, Hartman PA. Properties of the amylase from Halobacterium halobium. J Bacteriol. 1970;104(1):601603.

8. Kobayashi T, Kanai H, Hayashi T, Akiba T, Akaboshi R, Horikoshi K. Haloalkaliphilic maltotriose-forming a-amylase from the archaebacterium Natronococcus sp. strain Ah-36. J Bacteriol. 1992;174:34393444.

9. Coronado M,Vargas C, Hofemeister J, Ventosa A, Nieto JJ. Production and biochemical characterization of and aamylase of the moderate halophile Halomonas meridiana. FEMS Microbiol Lett. 2000;183:67-71.

10. Pérez-Pomares F, Díaz S, Bautista V, Pire C, Bravo G, Esclapez J, Zafrilla B, Bonete MJ. Identification of several intracellular carbohydrate- degrading activities from the halophilic archaeon Haloferax mediterranei Extremophiles. 2009;13:633-641.

11. Rodriguez-Valera F, Juez G, Kushner DJ. Halobacterium mediterranei spec. nov., a new carbohydrate-utilizing extreme halophile. Syst Appl Microbiol. 1983;4: 369-387
12. Haseltine $C$, Rolfsmeier $M$, Blum $P$. The glucose effect and regulation of the aamylase synthesis in the hyperthermophilic archaeon Sulfolobus solfataricus. J Bacteriol. 1996;178:4:945-950.

13. Bernfeld P. Amylases: Alpha and beta methods. Enzymology. 1955;1:149-158.

14. Bradford MM. A rapid and sensitive method for the quantification of microgram quantities of proteins utilizing the principle of protein-dye binding. Anal Biochem. 1976;72:248-254.

15. Segel IH. Enzyme kinetics. Behavior and analysis of rapid equilibrium and steadystate enzyme system. Wiley, New Yorkp; 1993.

16. Bonete MJ, Pérez-Pomares $F$, Díaz $S$, Ferrer J, Oren A. Occurrence of two different glutamate dehydrogenase activities in the halophilic bacterium Salinibacter ruber. FEMS Microbiol Lett. 2003;12;226(1):181-6.

17. Bhutto MA, Dahot MU. Effect of alternative carbon and nitrogen sources on production of alpha-amylase by Bacillus megaterium. World Applied Sciences Journal of Biotechnology \& Genetic Engineering). 2010; 8(Special Issue):85-90.

18. Deb P, Talukdar SA, Mohsina K, Sarker PK, AbuSayem SM. Production and partial characterization of extracellular amylase enzyme from Bacillus amyloliquefaciens P001. Springer Plus. 2013;2:154-163.

19. Suribabu K, Lalitha Govardhan T, Hemalatha KPJ. Optimization of various Nitrogen sources for the production of $\alpha-$ Amylase using Brevibacillus borstelensis R1 by Submerged fermentation. International Journal of Current Microbiology and Applied Sciences. 2014; 3(4):791-800.

20. Arotupin DJ, Ogunmolu FE. Experimental Investigations on the Effects of Carbon and Nitrogen Sources on Concomitant Amylase and Polygalacturonase Production by Trichoderma viride BITRS1001 in Submerged Fermentation. Biotechnology Research International. ID 904763. 2012; 1-8

21. Gomes I, Gomes J, Steiner W. Highly thermostable amylase and pullulanase of the extreme thermophilic eubacterium Rhodothermus marinus: production and partial characterization Bioresource Technology. 2003;90(2):207-214. 
22. Pire $\mathrm{C}$, Martínez-Espinosa $\mathrm{M}$, PérezPomares F, Esclapez J, Bonete MJ. Ferredoxin-dependent glutamate synthase: Involvement in ammonium assimilation in Haloferax mediterranei. Extremophiles 2014;18:147-159.
23. Mahmood S, Rahman SR. Production and partial characterization of extracellular $\alpha$ amylase by Trichoderma viride. Bangladesh J Microbiol. 2008;25(2):99103.

(c) 2018 Pérez-Pomares et al.; This is an Open Access article distributed under the terms of the Creative Commons Attribution License (http://creativecommons.org/licenses/by/4.0), which permits unrestricted use, distribution, and reproduction in any medium, provided the original work is properly cited.

Peer-review history:

The peer review history for this paper can be accessed here: http://www.sciencedomain.org/review-history/26355 